OPEN ACCESS

Edited by:

Raquel Vaquer-Sunyer, Instituto Mediterráneo de Estudios

Avanzados (IMEDEA), Spain

Reviewed by:

Mónica Torres-Beltrán,

The University of British Columbia

Canada

Ulf Karsten,

University of Rostock, Germany Jana Woelfel,

University of Rostock, Germany

*Correspondence:

Frank Wenzhöfer

frank.wenzhoefer@awi.de

Ulrike Braeckman

Ulrike.Braeckman@UGent.be

Specialty section This article was submitted to Coastal Ocean Processes, a section of the journal

Frontiers in Marine Science

Received: 12 August 2018 Accepted: 07 October 2019 Published: 29 October 2019

Citation:

Hoffmann R, Al-Handal AY Wulff A, Deregibus D, Zacher K,

Quartino ML, Wenzhöfer F and Braeckman U (2019) Implications of Glacial Melt-Related Processes on the Potential Primary Production of a Microphytobenthic Community

in Potter Cove (Antarctica).

Front. Mar. Sci. 6:655.

doi: 10.3389/fmars.2019.00655

\section{Implications of Glacial Melt-Related Processes on the Potential Primary Production of a Microphytobenthic Community in Potter Cove (Antarctica)}

\author{
Ralf Hoffmann ${ }^{1}$, Adil Yousif Al-Handal'2, Angela Wulff', Dolores Deregibus ${ }^{3}$, \\ Katharina Zacher ${ }^{1}$, María Liliana Quartino ${ }^{3}$, Frank Wenzhöfer ${ }^{1,4 *}$ and Ulrike Braeckman ${ }^{5 *}$ \\ ${ }^{1}$ Alfred Wegener Institute Helmholtz Centre for Polar and Marine Research (AWI), Bremerhaven, Germany, ${ }^{2}$ Department \\ of Biological and Environmental Sciences, University of Gothenburg, Gothenburg, Sweden, ${ }^{3}$ Instituto Antártico Argentino, \\ Buenos Aires, Argentina, ${ }^{4}$ HGF-MPG Joint Research Group for Deep-Sea Ecology and Technology, Max Planck Institute \\ for Marine Microbiology, Bremen, Germany, ${ }^{5}$ Marine Biology Research Group, Ghent University, Ghent, Belgium
}

The Antarctic Peninsula experiences a fast retreat of glaciers, which results in an increased release of particles and sedimentation and, thus, a decrease in the available photosynthetic active radiation (PAR, 400-700 nm) for benthic primary production. In this study, we investigated how changes in the general sedimentation and shading patterns affect the primary production by benthic microalgae, the microphytobenthos. In order to determine potential net primary production and respiration of the microphytobenthic community, sediment cores from locations exposed to different sedimentation rates and shading were exposed to PAR of $0-70 \mu \mathrm{mol}$ photons $\mathrm{m}^{-2} \mathrm{~s}^{-1}$. Total oxygen exchange rates and microphytobenthic diatom community structure, density, and biomass were determined. Our study revealed that while the microphytobenthic diatom density and composition remained similar, the net primary production of the microphytobenthos decreased with increasing sedimentation and shading. By comparing our experimental results with in situ measured PAR intensities, we furthermore identified microphytobenthic primary production as an important carbon source within Potter Cove's benthic ecosystem. We propose that the microphytobenthic contribution to the total primary production may drop drastically due to Antarctic glacial retreat and related sedimentation and shading, with yet unknown consequences for the benthic heterotrophic community, its structure, and diversity.

Keywords: Antarctic benthic diatoms, effects of sedimentation, environmental photosynthetic active radiation, primary production efficiency, Southern Ocean, oxygen flux, carbon flux

\section{INTRODUCTION}

The Antarctic Peninsula is one of the fastest warming areas on Earth (Ducklow et al., 2007). As a result, glaciers in the West Antarctic (Paolo et al., 2015) and especially at the Western Antarctic Peninsula (Rückamp et al., 2011; Cook et al., 2016) are melting and retreating. Vast amounts of particles are released into the water column with the start of the melting season in spring, which 
leads to increased turbidity (Dierssen et al., 2002) and sedimentation (Schloss et al., 1999; Pasotti et al., 2015). In addition, glacial melt also induces ice scouring, leading to particle resuspension at the soft bottom seafloor and therefore, to an additional increase in turbidity (Barnes, 1999; Griffiths, 2010).

Consequently, the photosynthetic active radiation (PAR, 400-700 $\mathrm{nm}$ ) can be reduced in areas influenced by glacial melt. This might affect the performance of primary producers, especially the primary production of benthic microalgae, the microphytobenthos (MPB) (Dayton et al., 1986; Skowronski et al., 2009), since they are dependent on the water depth-related light attenuation. Since shallow Antarctic waters can be very low in phytoplankton biomass and production (Hapter et al., 1983; Schloss et al., 1997, 1998, 2002), MPB can contribute substantially to the total primary production in the coastal Antarctic marine realm. For example, McMinn et al. (2010) reported that the MPB primary production at Casey Station, East Antarctica can be responsible for up to $90 \%$ of the total primary production during the sea ice free season. Antarctic MPB is dominated by diatoms (Wulff et al., 2009). Dominant diatom species such as Cocconeis spp., Gyrosigma fasciola, Navicula cf. cancellata, Petroneis plagiostoma, and Pleurosigma obscurum (AlHandal and Wulff, 2008a; Wulff et al., 2008b) are known to cope well with low light conditions (Palmisano et al., 1985; Rivkin and Putt, 1987; Longhi et al., 2003; Gómez et al., 2009), which are often associated with ice cover. Many benthic diatom species can survive dark periods by means of heterotrophic processes and they efficiently adjust their photosynthetic activity to the actual radiation (reviewed in Karsten et al., 2012). In future warming scenario's, the relative importance of MPB could possibly increase, as the earlier melt of sea ice reduces sea ice algae production and phytoplankton blooms become nutrient-limited in early summer, whereas MPB has direct access to nutrients released from the sediment (McMinn et al., 2010). However, the glacial melt-related particle release and related intensive shading and burial of MPB communities might put a negative feedback on this enhanced role for MPB primary production.

The benthos in Potter Cove (King George Island/Isla 25 de Mayo) experiences different intensities of turbidity and sedimentation (Schloss et al., 1999; Pasotti et al., 2015; Deregibus et al., 2016), owing to the retreating Fourcade Glacier (Rückamp et al., 2011) and the general current system. Water masses from Maxwell Bay enter the cove at the northern shore site, circulate clock-wise with an average current speed of $0.03 \mathrm{~m} \mathrm{~s}^{-1}$ along the front of the Fourcade glacier and leave the cove at the southern shore site (Lim et al., 2013). The melting and retreating glacier and also seasonal meltwater discharge, a consequence of permafrost and snow thawing, release a high number of particles into the cove (Klöser et al., 1993; Schloss et al., 1999, 2012). As a consequence, a turbidity gradient is created with a low turbidity on the northern shore site, a high turbidity at the glacial front and an intermediate turbidity at the southern shore site (Klöser et al., 1993; Quartino et al., 2013; Sahade et al., 2015; Monien et al., 2017).

In this study, we exposed sediment cores from different locations to increasing PAR and measured the resulting total oxygen flux. Further, we determined the diatom density, which dominates the MPB community (Al-Handal and Wulff, 2008a; Wulff et al., 2008a,b), and identified the diatom community structure at each location to assess small-scale differences and estimated the diatom biomass. The aim of this study was to investigate if glacial melt-related particle release and related shading and sedimentation are able to influence the primary production of an Antarctic MPB assemblage. To address this question, we tested the two null hypotheses that (a) the diatom community structure and density are comparable among areas experiencing different shading and sedimentation and, (b) that the MPB community primary production is similar among areas experiencing different intensities of sedimentation and shading. In addition, we compared our results with in situ PAR data, measured over 1 year. This enables us to discuss the importance of MPB primary production as organic carbon source for Potter Cove's benthic heterotrophic community from the radiation perspective.

\section{MATERIALS AND METHODS}

\section{Study Site and Sampling}

The study was conducted at the Dallmann Laboratory annex of the Carlini research station, located at the roughly $3 \mathrm{~km}$ long and $1.2 \mathrm{~km}$ wide Potter Cove. The cove is a shallow, fjord-like inlet of Maxwell Bay on King George Island/Isla 25 de Mayo (South Shetland Islands, Western Antarctic Peninsula). Potter Cove is regularly covered by sea ice during winter (Schloss et al., 2012) and experienced a fast retreat of the Fourcade glacier within the last decades (Rückamp et al., 2011). Our sampling sites are located in 6-9 $\mathrm{m}$ water depth and in a radius of less than $1 \mathrm{~km}$ distance to each other (Figure 1 and Table 1). The locations, namely Creek, Faro and Isla D, became free of glacial ice before the 1950s, between 1988 and 1995, and before 2005, respectively (Rückamp et al., 2011), but are regularly covered by sea ice during winter (Schloss et al., 2012). The three locations experience different intensities of glacial melt-related effects. Due to the generally clock-wise current-flow around Potter Cove (average current speed of $0.03 \mathrm{~m} \mathrm{~s}^{-1}$; Lim et al., 2013), the amount of suspended particulate matter in the water column is highest at the glacier front (Isla D) and downstream (Creek; 13-315 mg $\mathrm{L}^{-1}$ ) and lowest upstream (Faro: 2.5-3.5 $\mathrm{mg} \mathrm{L}^{-1}$ ) (Monien et al., 2017). The turbidity at Faro and Creek is usually similar, while Isla $\mathrm{D}$ is generally characterized by a higher turbidity (based on interpolation of data from Deregibus et al., 2016). The sediment accumulation is lowest at Faro, intermediate at Creek, and highest at Isla D (Pasotti et al., 2015). The median grain size is therefore very small at Isla $\mathrm{D}(\sim 20 \mu \mathrm{m})$ with a high silt fraction $(83 \%)$, whereas at Faro and Creek fine sand is found (median grain size: $\sim 120 \mu \mathrm{m}$ ) with a silt fraction of 39 and $28 \%$, respectively (Hoffmann et al., 2018). The three investigated sites have a sediment TOC content of $0.2 \%$ (Hoffmann et al., 2018). The benthic community in the sediments at this water depth is in terms of biomass dominated by macrofauna $\left(129 \mathrm{~g} \mathrm{C} \mathrm{m}^{-2}\right.$ in Creek, $118 \mathrm{~g} \mathrm{C} \mathrm{m}^{-2}$ in Isla D, and $92 \mathrm{~g} \mathrm{C} \mathrm{m}^{-2}$ in Faro), to which the burrowing bivalve Laternula elliptica contributes 39-41\% at Faro and Creek, but even $81 \%$ at Isla D (Hoffmann et al., 2018). 


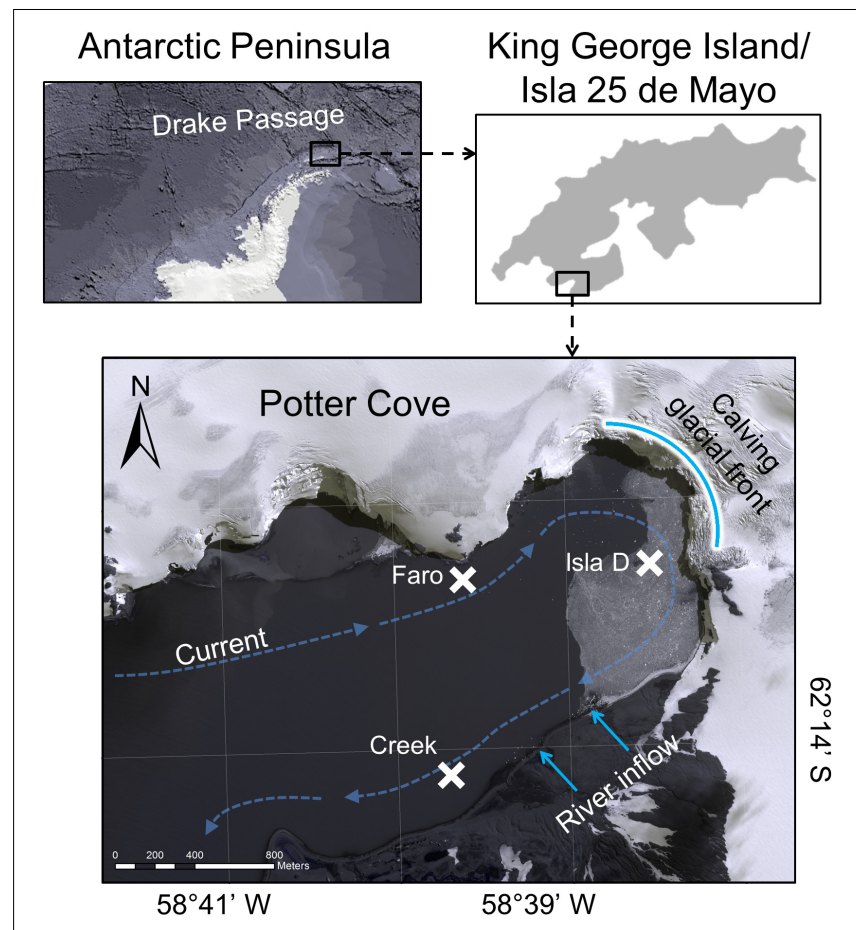

FIGURE 1 | Study site Potter Cove. At Faro, Creek, and Isla D, sediment cores for microphytobenthic analyses and primary production estimates were recovered by SCUBA divers. The position of sampled locations is marked with a cross. The curved, bright blue line marks the front of the Fourcade glacier. The bright blue arrows indicate river run-offs supplied mainly by glacier, permafrost, and snowmelt water. The dashed blue arrows indicate the direction of the main current in Potter Cove. More detailed information about the locations is given in Table $\mathbf{1}$

Triplicates of small sediment cores $(10 \mathrm{~cm}$ length, $3.6 \mathrm{~cm}$ diameter) were taken at each location by SCUBA divers between November 5, 2016 and November 11, 2016 to quantify chlorophyll- $a$ (Chl-a) concentrations and MPB community structure (Table 1). For primary production estimates, five larger sediment cores (50 cm length, $10 \mathrm{~cm}$ diameter) were collected between November 22, 2016 and December 11, 2016 by SCUBA divers (Table 1). One large sediment core was subsampled for an additional MPB community sample as described above, while the four remaining sediment cores were used for primary production estimates. During recovery and transport to the laboratory, the sediment cores were kept vertical and special care was taken to leave the sediment surface undisturbed. All samples were processed within $1.5 \mathrm{~h}$ after recovery.

\section{In situ PAR Measurement}

To assess whether the underwater PAR at the three locations allowed MPB primary production, in situ PAR measurements were conducted. Close to Faro (62 $\left.13.35^{\prime} \mathrm{S}, 58^{\circ} 40.47^{\prime} \mathrm{W}\right)$ and at Isla $\mathrm{D}\left(62^{\circ} 13.31^{\prime} \mathrm{S}, 58^{\circ} 38.30^{\prime} \mathrm{W}\right)$ Odyssey PARsensors (Odyssey Photosynthetic Irradiance Recording System, Data Flow Systems, Christchurch, New Zealand) were installed approximately $0.5 \mathrm{~m}$ above the seafloor at $10 \mathrm{~m}$ water depth in 2015. Data from Faro encompass a 12-month period, while data
TABLE 1 | Locations, water depth at sampled locations, and date of sampling.

\begin{tabular}{lccc}
\hline & Faro & Creek & Isla D \\
\hline Latitude S & $62^{\circ} 13.31^{\prime}$ & $62^{\circ} 14.8^{\prime}$ & $62^{\circ} 13.30^{\prime}$ \\
Longitude W & $58^{\circ} 39.37^{\prime}$ & $58^{\circ} 39.43^{\prime}$ & $58^{\circ} 38.30^{\prime}$ \\
Depth (m) & $8-9$ & $7-8$ & $8-9$ \\
Microphytobenthic and & November & November & November \\
Chl-a sampling (Date) & 5,2016 & 11,2016 & 9,2016 \\
Sediment core sampling for & November & December & December \\
primary production & 22,2016 & 3,2016 & 11,2016 \\
estimates (Date) & & &
\end{tabular}

from Isla D only encompass the period February 11-April 4 and November 16-December 31, as the sensor was damaged probably by chunks of ice. These PAR-sensors were calibrated according to Deregibus et al. (2016) and measured with a temporal resolution of $30 \mathrm{~min}$. At Creek ( $\left.62^{\circ} 14.08^{\prime} \mathrm{S}, 58^{\circ} 39.43^{\prime \prime} \mathrm{W}\right)$ a Li-Cor PAR sensor (LI-192, Li-Cor Biosciences, Lincoln, NE, United States; factory calibrated), measured with a temporal resolution of $1 \mathrm{~s}$ for $36 \mathrm{~h}$ from November 10 to November 11 during the field campaign in 2016.

\section{Chlorophyll-a Concentration of in situ Sediment}

Sediment subsamples were taken from the small cores with cutoff syringes (cross-sectional area $=1.65 \mathrm{~cm}^{2}$ ) and the upper $\mathrm{cm}$ was stored at $-80^{\circ} \mathrm{C}$. Chl- $a$ concentrations were determined in the home lab by HPLC (Gilson) (Wright and Jeffrey, 1997). Chl- $a$ concentrations $\left(\mu \mathrm{g} \mathrm{g}^{-1}\right)$ were integrated to surface $\left(\mathrm{mg} \mathrm{m}^{-2}\right)$ by taking grain density and porosity into account.

\section{Diatom Density, Biomass, and Community Structure}

To investigate the diatom community of the MPB, the upper $0.5 \mathrm{~cm}$ sediment layer of a sediment core was transferred into a scintillation vial and $5 \mathrm{~mL}$ GF/F filtered seawater (Whatman, United Kingdom) and $1 \mathrm{~mL}$ of $25 \%$ glutaraldehyde were added. The vial was wrapped in parafilm (Bemis Company, United States) and stored at $4^{\circ} \mathrm{C}$ until further analyses.

Diatoms, the major components of microphytobenthos in the study area (Al-Handal and Wulff, 2008a; Wulff et al., 2008a,b), were identified and counted. Diatom valves were cleaned with $30 \%$ hydrogen peroxide and, after proper rinsing with deionized water, mounted in Naphrax after Al-Handal and Wulff (2008a). Identification of taxa was made following established protocols (Witkowski et al., 2000; Scott and Thomas, 2005; Al-Handal and Wulff, 2008a,b). Enumeration of diatom valves on the slides was made by counting intact valves on the whole slide using a Zeiss Axio Image 2 compound microscope equipped with differential interphase contrast under 400-fold magnification. During the identification of taxa, the length and width of pennate valves and the diameter of centric valves were measured using a micrometer. The average length and width of at least 30 valves per taxon and the assumed height of $1 \mu \mathrm{m}$ (Edler, 1979) were used to calculate the biovolume of diatom cells (Hillebrand et al., 1999; Sun and Liu, 2003). The diatom cell 
biovolumes were converted into diatom carbon biomass using a conversion factor of $0.089 \mathrm{pg} \mathrm{C} \mathrm{mm}^{-3}$ cell $^{-1}$ biovolume $\mathrm{p}^{-1}$ (Sundbäck et al., 1996). Very large cells, e.g., of Gyrosigma sp. can be overseen during the applied method. Therefore, diatom density and diatom biomass data were slightly underestimated (see section "Discussion"). The Shannon-Wiener diversity index H’ was calculated using Primer v6.

\section{Diatom Carbon Biomass - Normalized Potential Primary Production Rates and Light Compensation Point}

To determine the potential primary production and the light compensation point of the MPB at the three locations, the remaining four large sediment cores were stored in a water bath with sea water at in situ temperature of $0.5^{\circ} \mathrm{C}$ and salinity 34. A magnetic stirrer was inserted in each sediment core. Vertically adjustable cold-light lamps (Osram Lumilux Cool Daylight L36W/865, Osram, Munich, Germany) were installed above the water bath and the emitted PAR was permanently controlled with a spherical PAR-sensor (US-SQS/L and ULM500, Walz, Germany). The spherical PAR-sensor was placed in an empty sediment core tube, covered with sea-water, and stored in the same water bath as the sediment cores. In order to measure the PAR that reached the sediment surface of the sediment cores during the experiment, the spherical PAR-sensor was adjusted to the lowest height of the sediment surface of the sediment cores. Furthermore, the PAR sensor tube was covered with a lid.

By adjusting the height of the cold-light lamps, the sediment cores were exposed to PAR intensities of $0,5,10,15,20,25$, 47 , and $70 \mu \mathrm{mol}$ photons $\mathrm{m}^{-2} \mathrm{~s}^{-1}$, starting with the lowest PAR. Sediment cores from Isla D were additionally exposed to $35 \mu \mathrm{mol}$ photons $\mathrm{m}^{-2} \mathrm{~s}^{-1}$. In order to enable the MPB to adjust to the experimental light conditions, the sediment cores were pre-incubated at each PAR intensity for $4 \mathrm{~h}$. During that period, the overlying water was permanently aerated and thereby kept homogeneous and oxygen-saturated. After the $4 \mathrm{~h}$ period, the sediment cores were closed airtight and the volume of the overlying water was determined. An optical oxygen microsensor (OXR50, Pyroscience, Aachen, Germany, tip size diameter $=50 \mu \mathrm{m})$, calibrated at in situ temperature with a two-point calibration using air saturated and anoxic waters (by adding sodium dithionite), was installed in the lid, which allowed a continuous measurement of the oxygen concentration in the overlying water.

The sediment cores were incubated at each PAR intensity for $\geq 3 \mathrm{~h}$. Measurements of oxygen concentrations were performed at a $2 \mathrm{~s}$ temporal resolution, while the overlying water was kept homogeneous by rotating magnets. The total oxygen exchange over the period of each PAR exposure was calculated using the formula:

$$
\text { Total oxygen exchange rate }=-\frac{\delta \mathrm{O}_{2} \times V}{\delta \mathrm{t} \times A}
$$

in which $\delta \mathrm{O}_{2}, \delta \mathrm{t}, V$, and $A$ represent the difference in oxygen concentration, the difference in time, the volume of the overlying water, and the enclosed surface area, respectively.
After the incubation, the sediment core was exposed to the next higher PAR intensity by adjusting the height of the coldlight lamps and the procedure for total oxygen exchange rate measurement was repeated. To avoid an oxygen oversaturation at the highest PAR, which would lead to an underestimation of the total oxygen exchange rate, the overlying water of the sediment cores was aerated with helium until an oxygen concentration of $240 \mu \mathrm{mol} \mathrm{O} \mathrm{L}^{-1}$ was reached (70\% oxygen saturation, controlled by above-mentioned oxygen microsensors). Total oxygen exchange rates were converted to carbon equivalents (C-flux) by applying the Redfield ratio of $\mathrm{C}$ : $\mathrm{O}=106: 138$ (Redfield, 1934; Redfield et al., 1963). A negative exchange rate is directed toward the sediment, while a positive exchange rate is directed toward the water column. Sediment surface normalized C-fluxes were plotted against PAR to create a PIcurve from which the light compensation point and the lightdependent primary production were derived. The aim of study was to compare the primary production of the MPB between Faro, Creek, and Isla D. As the primary production of a MPB assemblage depends on surface area and biomass, the sediment surface-normalized C-fluxes of each location were also normalized to the mean diatom carbon content, assuming that $1 \mathrm{mg} \mathrm{C} \mathrm{cm}{ }^{-3}$ sediment $^{-1}$ equals $1 \mathrm{mg} \mathrm{C} \mathrm{cm}^{-2}$ sediment $^{-1}$. The sediment surface and biomass normalized C-fluxes were also plotted against the used PAR incidence intensities. The oxygen and carbon fluxes represent benthic community net fluxes, as microbial and faunal respiration processes are included. Consequently and owing to the experimental conditions, the calculated primary production needs to be assessed as potential net primary production.

\section{Statistical Analyses}

To test whether MPB densities, $\mathrm{H}^{\prime}$ and the slopes of C-fluxes and diatom carbon content-normalized C-fluxes differed among locations, a one-way ANOVA (type III SS) and a Tukey post hoc test was performed. A Shapiro-Wilk test was performed to test data normality, whereas a Levene's test was used to test homoscedasticity. In case data were not homoscedastic, an adjusted one-way ANOVA and a non-parametric Games-Howell post hoc test (Games and Howell, 1976) was performed to identify locations showing significant differences. The tests were performed using $\mathrm{R}$ Statistical Software (version 3.4.0, R Core Team, 2017) and the packages "CAR" (Fox and Weisberg, 2011) and "Userfriendlyscience" (Peters, 2007).

Analyses of the multivariate diatom community structure were based on square root transformed density data of sediment core replicates. Non-metric multidimensional scaling (MDS, after Kruskal, 1964) and hierarchical cluster analysis with group average clustering were used to present the multivariate similarities between samples based on Bray-Curtis similarity. The significance of multivariate differences between locations within the MPB community data was tested by the ANOSIM procedure (ANalysis Of SIMilarity) based on Clarke's R statistic (Clarke and Warwick, 1994) with 5775 permutations (number of all possible permutations). The SIMPER (SIMilarity PERcentage) routine was applied to determine the contribution of certain MPB taxa toward the discrimination between the locations. The tests 
regarding the MPB community were conducted using Primer v6. Results are expressed as mean values \pm standard deviation.

\section{RESULTS}

\section{In situ PAR Variability and Sediment Chl-a Concentration}

The in situ PAR, investigated on seasonal and daily temporal scales as well as on spatial scales (Figure 2), showed a high variability. The daily maximum PAR in 2015 at Faro (Figure 2A) in spring (October-November) ranged between 3 and $208 \mu \mathrm{mol}$ photons $\mathrm{m}^{-2} \mathrm{~s}^{-1}$, in summer (December-March) between 1 and $126 \mu \mathrm{mol}$ photons $\mathrm{m}^{-2} \mathrm{~s}^{-1}$, in autumn (April-May) between 0 and $49 \mu \mathrm{mol}$ photons $\mathrm{m}^{-2} \mathrm{~s}^{-1}$, and in winter (JuneSeptember) between 0 and $102 \mu \mathrm{mol}$ photons $\mathrm{m}^{-2} \mathrm{~s}^{-1}$. The winter period includes days during which the sea ice in Potter Cove had already broken up, which explains the maximum PAR of $102 \mu \mathrm{mol}$ photons $\mathrm{m}^{-2} \mathrm{~s}^{-1}$ during winter. However, when only the winter period until the sea ice break-up is considered (June-September 27), the daily maximum PAR at Faro in winter 2015 reached $12 \mu \mathrm{mol}$ photons $\mathrm{m}^{-2} \mathrm{~s}^{-1}$. At Isla D (Figure 2B), the daily maximum PAR within spring (November) ranged between 12 and $91 \mu \mathrm{mol}$ photons $\mathrm{m}^{-2} \mathrm{~s}^{-1}$ and within summer (December and February-March) between 0 and $116 \mu \mathrm{mol}$ photons $\mathrm{m}^{-2} \mathrm{~s}^{-1}$. The daily maximum PAR at Creek (Figure 2C) reached $555 \mu \mathrm{mol}$ photons $\mathrm{m}^{-2} \mathrm{~s}^{-1}$ on November 10, 2016 and $277 \mu \mathrm{mol}$ photons $\mathrm{m}^{-2} \mathrm{~s}^{-1}$ on November 11, 2016. The
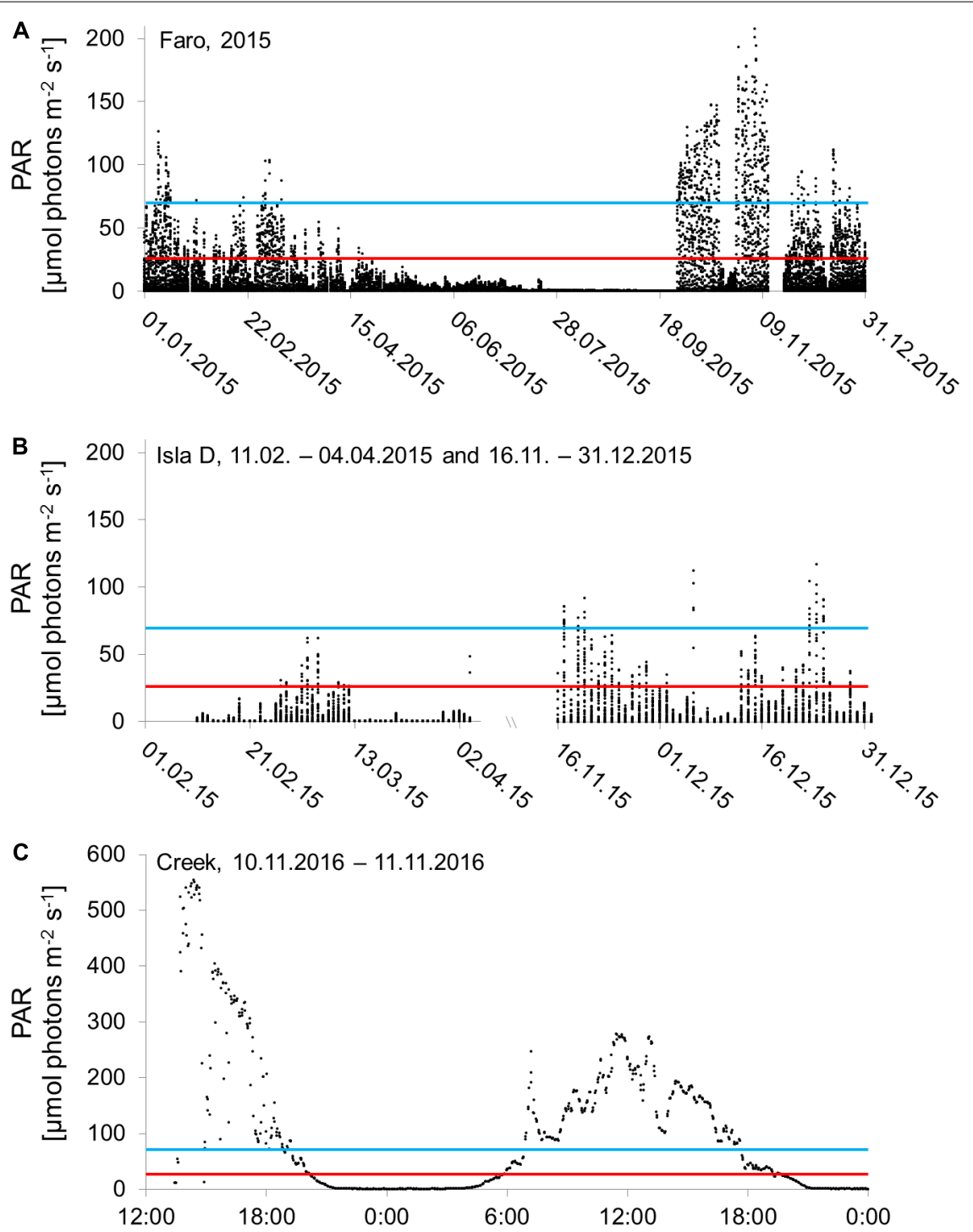

FIGURE 2 | In situ measured photosynthetically active radiation intensities (PAR) on a seasonal scale at (A) Faro (entire year 2015), (B) and Isla D (February 11, 2015-April 4, 2015 and November 16, 2015-December 31, 2015), and on a daily scale at (C) Creek (November 10, 2016-November 11, 2016). The red line marks the light compensation point of $26 \mu \mathrm{mol}$ photons $\mathrm{m}^{-2} \mathrm{~s}^{-1}$ and the bright blue line the maximum PAR used during the experiment presented in this study. 
PAR results indicate that effects of sedimentation and shading vary strongly among the study locations on temporal and spatial scales resulting in strong diurnal variability in maximum photosynthetically available light energy in Potter Cove.

In accordance with these local differences in in situ PAR availability, Chl- $a$ concentrations at the sediment surface were highest at Creek $\left(239 \pm 134 \mathrm{mg} \mathrm{m}^{-2}\right)$, lower at Faro $\left(145 \pm 48 \mathrm{mg} \mathrm{m}^{-2}\right)$ and lowest at Isla D $(44 \pm 18 \mathrm{mg}$ $\mathrm{m}^{-2}$ ). This can be of MPB, but also planktonic and macroalgal origin.

\section{Diatom Community Composition at Potter Cove}

Overall 48 diatom species were found in the upper $0.5 \mathrm{~cm}$ sediment layer (Supplementary Table S1) with G. fasciola as dominant species at all three locations $(30 \pm 15 \%$ at Faro, $40 \pm 20 \%$ at Creek, $44 \pm 18 \%$ at Isla D). In total, nine pelagic species were found, which made up 8, 12, and $7 \%$ of the diatom density at Faro, Creek, and Isla D, respectively (Supplementary Table S1). The diatom density was $24912 \pm 6295,93243 \pm 44417$, and $42305 \pm 33413$ cells $\mathrm{cm}^{-2}$, diatom biomass was $23.5 \pm 7.2,67.9 \pm 30.3$, and $37.9 \pm 26.7 \mathrm{mg} \mathrm{C} \mathrm{m}{ }^{-2}$ at Faro, Creek, and Isla D, respectively. H' was $3.25 \pm 0.24$ at Faro, $2.43 \pm 0.28$ at Creek, and $2.93 \pm 0.82$ at Isla D. Diatom densities, biomasses, and $H^{\prime}$ did not show significant differences between the locations $\left(p_{\text {density }}=0.07, p_{\text {biomass }}=0.11, p_{H^{\prime}}=0.21\right)$. The ANOSIM results (Global $R=0.236, p$-value $=0.058$ ) indicated no significant differences in the diatom community structure among the three locations, which was confirmed by the SIMPER (dissimilarity between groups $<50 \%$, Supplementary Table S2).

\section{Potential Net MPB Primary Production in Potter Cove}

At each location, the C-flux increased with increasing PAR. Faro and Creek showed similar slopes $(p$-value $=0.876)$, whereas the slope at Isla D was significantly lower compared to Faro $(p$-value $=0.010)$ and Creek $(p$-value $=0.009$; Figure 3 and Table 2). The community respiration (C-flux in darkness) at Faro, Creek, and Isla $\mathrm{D}$ was $-18 \pm 1$, $-21 \pm 2$, and $-14 \pm 2 \mathrm{mmol} \mathrm{C} \mathrm{m}^{-2} \mathrm{~d}^{-1}$, respectively. The light compensation point for the MPB community was reached at $26 \mu \mathrm{mol}$ photons $\mathrm{m}^{-2} \mathrm{~s}^{-1}$ at Faro and Creek, whereas no light compensation point was reached at Isla D. The maximum net primary production at Faro was at $70 \mu$ mol photons $\mathrm{m}^{-2} \mathrm{~s}^{-1}\left(47 \pm 16 \mathrm{mmol} \mathrm{C} \mathrm{m}^{-2} \mathrm{~d}^{-1}\right)$ and at Creek at $47 \mu \mathrm{mol}$ photons $\mathrm{m}^{-2} \mathrm{~s}^{-1}(41 \pm 10 \mathrm{mmol}$ C $\left.\mathrm{m}^{-2} \mathrm{~d}^{-1}\right)$. At Isla $\mathrm{D}$, no net primary production was observed (Figure 3).

The diatom carbon content-normalized C-fluxes also increased with increasing PAR and showed significant differences regarding their slopes (Figure 4 and Table 2). The slope steepness was 0.208 at Faro, 0.064 at Creek, and 0.0178 at Isla D, indicating different net primary production by the MPB community at the three locations.

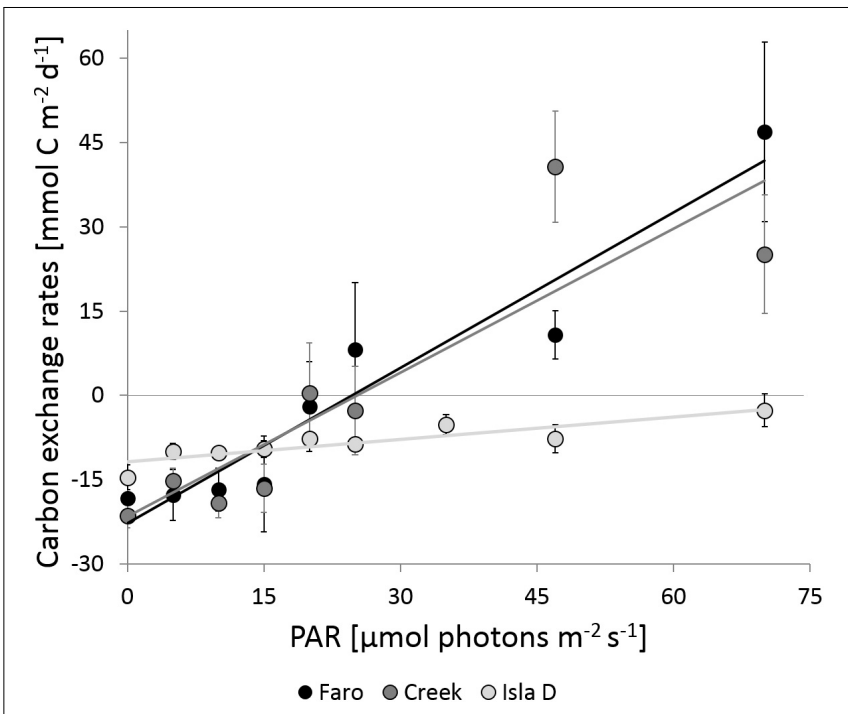

FIGURE 3 | Carbon exchange rates at different PAR intensities. Negative exchanges rates are net respiration and positive exchange rates net primary production of the benthic community. The linear regression for Faro, Creek, and Isla $D$ was $y=0.9221 x-22.72\left(R^{2}=0.925\right), y=0.8536 x-21.59$ $\left(R^{2}=0.781\right)$, and $y=0.1327 x-11.83\left(R^{2}=0.779\right)$, respectively.

TABLE 2 | $p$-values of ANOVAs and Games-Howell post hoc tests regarding sediment core specific slopes of C-fluxes (Figure 3 ) and diatom carbon content-normalized C-fluxes (Figure 4), both plotted against PAR.

\begin{tabular}{lclc}
\hline Flux & $\begin{array}{c}\text { ANOVA } \\
\text { (p-value) }\end{array}$ & $\begin{array}{l}\text { Grouped } \\
\text { locations }\end{array}$ & $\begin{array}{c}\text { Games-Howell post hoc } \\
\text { test (p-value) }\end{array}$ \\
\hline C-flux & $<0.001$ & Faro-Creek & 0.876 \\
& & Faro-Isla D & 0.010 \\
Diatom carbon & $<0.001$ & Freek-Isla D & 0.009 \\
content-normalized & & Faro-Isla D & 0.017 \\
C-fluxes & & Creek-Isla D & 0.009 \\
& & & 0.011 \\
\hline
\end{tabular}

\section{DISCUSSION}

\section{The Impact of Turbidity and Sediment Accumulation on the Microphytobenthic Community and Their Primary Production in Potter Cove}

Our findings indicate that glacial melt - related processes can decrease the primary production of an Antarctic MPB assemblage. The melting Fourcade glacier releases particles into Potter Cove, both directly and indirectly via river runoffs (Sahade et al., 2015; Monien et al., 2017). Due to their location and the current system in Potter Cove, the investigated locations were permanently and naturally exposed to contrasting intensities of perturbation (Pickett et al., 1989), a consequence of the turbidity and the sediment accumulation regime (Pasotti et al., 2015; Deregibus et al., 2016). The primary production of the MPB decreased with increasing perturbation closer to the glacier, and a net primary production was even completely suppressed at 


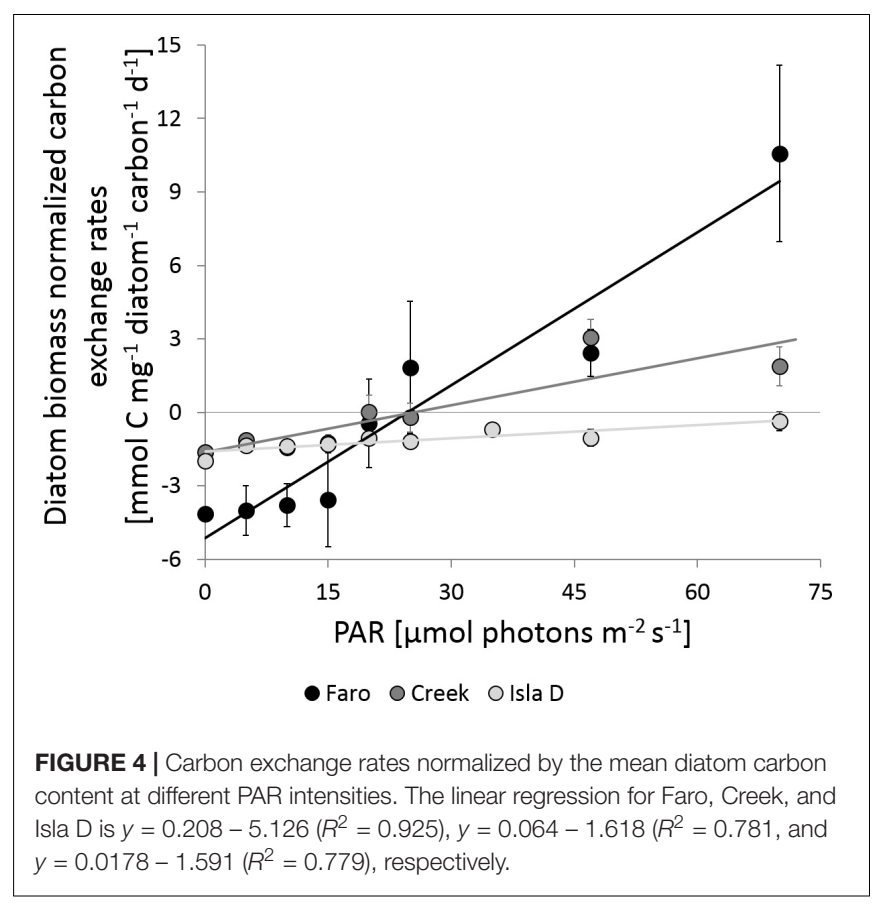

the glacier front (Isla D). This is remarkable, since large brownish mats were visible at Isla D during summer 2015, indicative of MPB presence (Hoffmann et al., 2018). However, the mats were not well developed at Isla D during our experiment in spring 2016 (Supplementary Figure S1). This indicates that the energy demand for growth and reproduction of the MPB community at Isla $\mathrm{D}$ seems to be covered by the photosynthetic apparatus during other periods of the year.

Microphytobenthos primary production estimates can be affected by light conditions, MPB community structure, heterotrophic processes - oxygen consumption by bacteria and infauna - and sediment accumulation. The high turbidity, representing low light conditions, seems to be less responsible for the observed pattern in primary production. Antarctic MPB is known for its exceptional adaption to low light conditions (Gómez et al., 2009), e.g., the median light saturation of an MPB community at Casey station was reached at $66 \mu \mathrm{mol}$ photons $\mathrm{m}^{-2} \mathrm{~s}^{-1}$ and 6-20 $\mu \mathrm{mol}$ photons $\mathrm{m}^{-2} \mathrm{~s}^{-1}$ were reported for an MPB community in the McMurdo Sound (Rivkin and Putt, 1987; McMinn et al., 2012). In Potter Cove, the light saturation was not investigated, but the light compensation point (net primary production and respiration are balanced) of $26 \mu \mathrm{mol}$ photons $\mathrm{m}^{-2} \mathrm{~s}^{-1}$ (this study) was frequently exceeded in spring. Therefore, the light conditions would allow a positive net primary production and a damage of the photosynthetic apparatus due to a low-light environment seems very unlikely. In addition, turbidity can affect the MPB community structure, which in turn might influence MPB primary production. Longhi et al. (2003) revealed differences in the low light adaption of Gyrosigma subsalinum var. antarctica and Odontella litigiosa, both species occurring in Potter Cove (Al-Handal and Wulff, 2008a; Wulff et al., 2008a,b; this study). We are not convinced that the species above were low light-adapted; they are rather acclimated to low light conditions. Therefore, we anticipated that in the present study, species preferring low light conditions would be dominant at Isla D and thereby change the MPB community structure. However, a difference in the diatom community structure, which dominates the MPB community (Al-Handal and Wulff, 2008a; Wulff et al., 2008a,b), was not observed among our three study locations. Therefore, the community structure is not responsible for the observed differences in the primary production of the MPB in Potter Cove. It should be noted, however, that in terms of biovolume, the e.g., large Gyrosigma spp. and Pleurosigma spp. are major community members in MPB around Potter Cove. For example, in Wulff et al. (2008a,b) G. fasciola and Gyrosigma spp. dominated the MPB community both in terms of cell numbers and biovolume (biomass). Similar observations were made in 2015-2016 (Braeckman et al., unpublished; Wulff et al., unpublished). In the applied cell counting method, these genera were likely underestimated due to cell breakage and it is recommended to count and measure these genera (and species of similar size) before treating the cells for mounting on slides.

In our study, bacterial biomass within the measured sediment cores was not quantified, but it is generally lower in sediments of Isla D compared to the other two locations (Braeckman et al., unpublished). No apparent differences in infaunal biomass were observed between the sediment cores from the three study locations. This means that the contribution of heterotrophic processes is not a main factor affecting spatial differences in net primary production.

We therefore assess sediment accumulation as the key factor responsible for the observed primary production pattern. It is known that pennate raphid diatoms are able to migrate vertically through the sediment. Diatom migration was observed as a reaction on tides, light, endogenous factors, perturbations, carbon dioxide concentration, and nutrient limitations (Consalvey et al., 2004, and references therein). The glacial melt-related sediment accumulation steadily covers the MPB community. As a consequence, the diatoms have to migrate over longer distances and migrate more often to locate themselves in the best available light conditions, as compared to MPB communities located in areas with lower sedimentation rates. In turn, the MPB community in high sedimentation areas needs more energy for migration, which lowers the overall net primary production. This applies to epipelic diatoms, which are highly motile (Round, 1979). Epipsammic diatoms are only able to move very slowly (Round, 1979) and would therefore be completely covered by sediments for a longer period. A full recovery in terms of their primary production would take more than 2 weeks (Wulff et al., 1997), and only if sediment accumulation ceases to cover the MPB community.

Some bias might have been introduced in the normalization of the C-fluxes, as three of four MPB samples, which were used for the normalization of the C-fluxes, were recovered 1 month before the sediment cores used for the primary production assessment. One additional MPB sample was recovered in parallel to the experimental sediment cores; however, differing from the other MPB samples in terms of diatom density and diatom carbon content. Whether this was due to temporal or spatial variability is hard to assess. Nevertheless, the diatom carbon biomass was 
observed to vary 3 -fold between the locations and the diatom density 5.5-fold, regardless of the potential temporal variation due to sample collection. The diatom density is within the 2- to 15 -fold range of spatial variability observed in other Antarctic MPB communities (Dayton et al., 1986; McMinn et al., 2012). Consequently, as we merged MPB samples from two different samplings dates and as spatial and temporal variability of MPB densities strongly overlap, our results cover both spatial and temporal variability in the MPB community.

\section{Microphytobenthos - An Important Carbon Source in Potter Cove}

Our study gives a first insight into the MPB primary production in Potter Cove and indicates that the MPB community could be an important carbon source for the benthic and pelagic food web. At the locations Faro and Creek, the MPB community is potentially able to fully supply the benthic carbon demand of 11-33 mmol C m $\mathrm{m}^{-2} \mathrm{~d}^{-1}$ at these locations (Hoffmann et al., 2018). As the MPB primary production at Faro and Creek even exceeded the benthic carbon demand (Hoffmann et al., 2018), benthic organisms in deeper water or in the pelagic could also be supplied by carbon from MPB primary production from these two locations. However, the carbon supply by MPB primary production is spatially limited and undergoes substantial temporal changes during spring. Thus, a permanent full supply of the benthic carbon demand only by MPB primary production during spring is unlikely. On the other hand, in combination with carbon from pelagic primary production (Schloss et al., 1998, 2012), the benthic carbon demand in Potter Cove would be fully supplied in spring and summer. Therefore, even if heterotrophic diatom growth (Lewin, 1953) and macroalgal primary production is not included in the estimate mentioned above, the available data suggest that Potter Cove is an autotrophic ecosystem in spring and summer months (Hoffmann et al., 2018).

We assess the obtained ex situ measured net MPB primary production values as reliable and transferable to in situ conditions. Although we applied a different methodology, the observed primary production by Potter Cove's MPB community under different PAR intensities was in a similar range as measured primary production of MPB communities from sand and mud sites at $15 \mathrm{~m}$ water depth in McMurdo Sound (0.1-190 mmol $\mathrm{C} \mathrm{m}^{-2} \mathrm{~d}^{-1},{ }^{14} \mathrm{C}$ method, Dayton et al., 1986), from sandy sediments at $8 \mathrm{~m}$ water depth at Signy Island (6-240 $\mathrm{mmol}$ $\mathrm{C} \mathrm{m}{ }^{-2} \mathrm{~d}^{-1},{ }^{14} \mathrm{C}$ method, Gilbert, 1991) and from sandy mud sites in water depths between 4 and $14 \mathrm{~m}$ at Casey Station (8$240 \mathrm{mmol} \mathrm{C} \mathrm{m} \mathrm{m}^{-2} \mathrm{~d}^{-1}$, in situ oxygen exchange rate calculated with Diffusive Boundary Layer method, McMinn et al., 2012). In addition, the community respiration (carbon flux measured in darkness) in this study was within the same range as in situ measured respiration rates of the benthic community in Potter Cove (Hoffmann et al., 2018). It needs to be mentioned that our experiment does not allow an evaluation, whether the measured PAR levels would cause photoinhibition, as in situ measured PAR exceeds the maximum of $70 \mu \mathrm{mol}$ photons $\mathrm{m}^{-2} \mathrm{~s}^{-1}$ used in our experiment. For example, photoinhibition can start at 25 and $100 \mu \mathrm{mol}$ photons $\mathrm{m}^{-2} \mathrm{~s}^{-1}$ in G. subsalinum and
O. litigiosa, respectively (Longhi et al., 2003). Comparing their results with the in situ PAR conditions in Potter Cove indicates that the MPB could experience dynamic photoinhibition during some periods. However, McMinn et al. (2012) reported that photoinhibition only becomes evident at actinic light levels above $413 \mu$ mol photons $\mathrm{m}^{-2} \mathrm{~s}^{-1}$. These high PAR intensities only occurred shortly at Creek, but in general in situ measured PAR in Potter Cove was below that value. In addition, results of Wulff et al. (2008a,b) and Zacher et al. (2007) did not reveal any photoinhibition in Antarctic marine microalgae when exposed to $600 \mu \mathrm{mol}$ photons $\mathrm{m}^{-2} \mathrm{~s}^{-1}$ or higher. Therefore, we believe that dynamic photoinhibition might affect a few diatom species, but the gross of the MPB at Faro, Creek and Isla D likely grows under either optimal or low light conditions.

\section{Implications of Glacial Melt-Related Retreat and Particle Release on Polar Benthic Communities}

The ongoing melt of Antarctic glaciers (Rückamp et al., 2011; Cook et al., 2016) might open up new settling ground for macroalgae (Quartino et al., 2013; Deregibus et al., 2016), benthic macrofauna (Lagger et al., 2017), and also MPB. Nevertheless, the melting of glaciers is related to the release of particles and as such leads to increased sediment accumulation (Pasotti et al., 2015; Monien et al., 2017). Sediment accumulation in turn, is known to trigger changes in the macrofauna community (Torre et al., 2012, 2017; Sahade et al., 2015), in macroalgae physiology (González et al., 2017), in benthic respiration (Hoffmann et al., 2018) and reduces MPB primary production (this study). MPB might survive increasing sedimentation rates (Wulff et al., 1997) but their contribution to the overall primary production as a food resource for the heterotrophic benthic fauna could possibly decline strongly or even cease directly at glacial fronts, as shown in our results. The question is then if increasing phytoplankton primary production (Kim et al., 2018) and newly available macroalgae biomass (Quartino et al., 2013; Campana et al., 2018) is able to replenish the food resource gap due to decreased MPB primary production that the heterotrophic community requires.

The effect of a reduced MPB primary production in highly perturbed areas due to intensive sediment accumulation (this study) seems to affect also MPB communities in the Arctic Ocean. In the Arctic Kongsfjorden, the MPB primary production was reduced at locations close to glacial fronts and riverine inflows (where high sedimentation rates are likely) compared to less perturbed locations (Woelfel et al., 2010). In the Arctic Ocean, the MPB primary production is an important carbon source in shallow coastal areas as it exceeds pelagic productivity by a factor of 1.5 for water depths down to $30 \mathrm{~m}$ (Glud et al., 2009; Attard et al., 2014). Consequently, the reduction of MPB primary production is likely to increase the food competition of the benthic heterotrophic community in both the Southern and the Arctic Ocean, with unpredictable consequences in biomass, density, structure and diversity for the benthic community. 


\section{AUTHOR CONTRIBUTIONS}

RH and FW initiated the study. RH developed the experimental setup, performed sediment sampling, in situ PAR measurement at the location "Creek," oxygen flux measurements and calculations, calculation of diatom biomasses, and statistical analyses, elaborated the figures, and wrote the first draft of the manuscript. $\mathrm{AA}-\mathrm{H}$ and $\mathrm{AW}$ analyzed the sediment samples regarding present diatom taxa and measured the diatom cell sizes. DD, KZ, and MQ provided in situ PAR data from the locations "Faro" and "Isla D." UB supervised oxygen flux measurements and interpretations of statistical analyses. FW was responsible for funding acquisition. All authors contributed to the manuscript revision, and read and approved the submitted version.

\section{FUNDING}

This research was funded by the European Union FP7 Project SenseOCEAN Marine Sensors for the 21st century (Grant Agreement No. 614141, www.senseocean.eu), by European Union FP7 Project IMCONet (Grant Agreement No. 319718), and by institutional funds of the Alfred-Wegener-Institut, Helmholtz-Zentrum für Polar- und Meeresforschung, of the Max

\section{REFERENCES}

Al-Handal, A. Y., and Wulff, A. (2008a). Marine benthic diatoms from potter cove. king george island, antarctica. Botanica Marina 51, 51-68. doi: 10.1515/BOT. 2008.007

Al-Handal, A. Y., and Wulff, A. (2008b). Marine epiphytic diatoms from the shallow sublittoral zone in potter cove, king george island, antarctica. Botanica Marina 51, 411-435. doi: 10.1515/BOT.2008.053

Attard, K. M., Glud, R. N., McGinnis, D. F., and Rysgaard, S. (2014). Seasonal rates of benthic primary production in a greenland fjord measured by aquatic eddy correlation. Limnol. Oceanogr. 59, 1555-1569. doi: 10.4319/lo.2014.59.5. 1555

Barnes, D. K. A. (1999). The influence of ice on polar nearshore benthos. J. Mar. Biol. Assoc. U.K. 79, 401-407. doi: 10.1017/s0025315498000514

Campana, G. L., Zacher, K., Deregibus, D., Momo, F. R., Wiencke, C., and Quartino, M. L. (2018). Long term succession of benthic algae in antarctica: structural patterns and glacial impact. Polar Biol. 41, 377-396. doi: 10.1007/ s00300-017-2197-x

Clarke, K. R., and Warwick, R. M. (1994). Similarity-based testing for community pattern: the two-way layout with no replication. Mar. Biol. 118, 167-176. doi: 10.1007/BF00699231

Consalvey, M., Paterson, D. M., and Underwood Graham, J. C. (2004). The ups and downs of life in a benthic biofilm: migration of benthic diatoms. Diatom Res. 19, 181-202. doi: 10.1080/0269249X.2004.9705870

Cook, A. J., Holland, P. R., Meredith, M. P., Murray, T., Luckman, A., and Vaughan, D. G. (2016). Ocean forcing of glacier retreat in the western antarctic peninsula. Science 353, 283-286. doi: 10.1126/science.aae0017

Dayton, P. K., Watson, D., Palmisano, A., Barry, J. P., Oliver, J. S., and Rivera, D. (1986). Distribution patterns of benthic microalgal standing stock at mcmurdo sound, antarctica. Polar Biol. 6, 207-213. doi: 10.1007/BF00443397

Deregibus, D., Quartino, M. L., Campana, G. L., Momo, F. R., Wiencke, C., and Zacher, K. (2016). Photosynthetic light requirements and vertical distribution of macroalgae in newly ice-free areas in potter cove, south shetland islands, antarctica. Polar Biol. 39, 153-166. doi: 10.1007/s00300-015-1679-y

Dierssen, H. M., Smith, R. C., and Vernet, M. (2002). Glacial meltwater dynamics in coastal waters west of the antarctic peninsula. Proc. Nat. Acad. Sci. U.S.A. 99, 1790-1795. doi: 10.1073/pnas.032206999
Planck Society, and of the University of Gothenburg. UB is a postdoctoral fellow at the Research Foundation - Flanders (FWO; Grant No. 1201716N).

\section{ACKNOWLEDGMENTS}

We would like to acknowledge the immense support of the staff and especially of the military divers at Carlini Station, which was essential for the success of our campaign. In addition, we thank Elisa Merz and Christopher Brunner for support during the campaign and Moritz Holtappels for providing the PAR data from Creek. Furthermore, we thank Christiane Hasemann for the statistical support on the diatom community structure. Finally, we would like to thank the editor and the reviewers for their constructive comments on the manuscript.

\section{SUPPLEMENTARY MATERIAL}

The Supplementary Material for this article can be found online at: https://www.frontiersin.org/articles/10.3389/fmars. 2019.00655/full\#supplementary-material

Ducklow, H. W., Baker, K., Martinson, D. G., Quetin, L. B., Ross, R. M., Smith, R. C., et al. (2007). Marine pelagic ecosystems: the west antarctic peninsula. Philos. T. Roy. Soc. B 362, 67-94. doi: 10.1098/rstb.2006.1955

Edler, L. (1979). Recommendations on Methods for Marine Biological Studies in the Baltic Sea. The Library Institute of Marine Research: Baltimore

Fox, J., and Weisberg, S. (2011). An $\{R\}$ Companion to Applied Regression, 2nd Edn, Available at: http://socserv.socsci.mcmaster.ca/jfox/Books/Companion (accessed April 03, 2019).

Games, P. A., and Howell, J. F. (1976). ). Pairwise multiple comparison procedures with unequal n's and/or variances: a monte carlo study. J. Educ. Behav. Stat. 1, 113-125. doi: 10.3102/10769986001002113

Gilbert, N. S. (1991). Primary production by benthic microalgae in nearshore marine sediments of signy island, antarctica. Pol. Biol. 11, 339-346. doi: 10. 1007/BF00239026

Glud, R. N., Woelfel, J., Karsten, U., Kühl, M., and Rysgaard, S. (2009). Benthic microalgal production in the arctic: applied methods and status of the current database. Botanica Marina 52, 559-571.

Gómez, I., Wulff, A., Roleda, M. Y., Huovinen, P., Karsten, U., Quartino, M. L., et al. (2009). Light and temperature demands of marine benthic microalgae and seaweeds in polar regions. Bot. Mar. 52, 593-608. doi: 10.1515/BOT.2009.073

González, P. M., Deregibus, D., Malanga, G., Campana, G. L., Quartino, M. L., and Puntarulo, S. (2017). Oxidative balance in macroalgae from antarctic waters. possible role of fe. J. Exp. Mar. Biol. Ecol. 486, 379-386. doi: 10.1016/j.jembe. 2016.10.018

Griffiths, H. J. (2010). Antarctic marine biodiversity - what do we know about the distribution of life in the southern ocean? PLoS One 5:e11683. doi: 10.1371/ journal.pone.0011683

Hapter, R., Wozniak, B., and Dobrowolski, K. (1983). Primary production in Ezcurra inlet during the antarctic summer of 1977/78. Oceanologia 15, 175-184.

Hillebrand, H., Dürselen, C.-D., Kirschtel, D., Pollingher, U., and Zohary, T. (1999). Biovolume calculation for pelagic and benthic microalgae. J. Phycol. 35, 403-424. doi: 10.1046/j.1529-8817.1999.3520403.x

Hoffmann, R., Pasotti, F., Vázquez, S., Lefaible, N., Torstensson, A., MacCormack, W., et al. (2018). Spatial variability of biogeochemistry in shallow coastal benthic communities of potter cove (antarctica) and the impact of a melting glacier. PLoS One 13:e0207917. doi: 10.1371/journal.pone.02 07917 
Karsten, U., Schlie, C., Woelfel, J., and Becker, B. (2012). Benthic diatoms in arctic seas-ecological functions and adaptions. Polarforschung 81, 77-84.

Kim, S.-H., Ducklow, D. H., Abele, D., Ruiz-Bartlett, E., Buma, A. G. J., Meredith, M. P., et al. (2018). Inter-decadal variability of phytoplankton biomass along the coastal west antarctic peninsula. Philos. Trans. A Math. Phys. Eng. Sci. 376:20170174. doi: 10.1098/rsta.2017.0174

Klöser, H., Ferreyra, G., Schloss, I., Mercuri, G., Laturnus, F., and Curtosi, A. (1993). Seasonal variation of algal growth conditions in sheltered antarctic bays: the example of potter cove (king george island, south shetlands). J. Mar. Syst. 4, 289-301. doi: 10.1016/0924-7963(93)90025-H

Kruskal, J. B. (1964). Multidimensional scaling by optimizing goodness of fit to a nonmetric hypothesis. Psychometrika 29, 1-27. doi: 10.1007/BF0228 9565

Lagger, C., Servetto, N., Torre, L., Sahade, R., and Belgrano, A. (2017). Benthic colonization in newly ice-free soft-bottom areas in an antarctic fjord. PLoS One 12:e0186756. doi: 10.1371/journal.pone.0186756

Lewin, J. C. (1953). Heterotrophy in diatoms. J. Gen. Microbial. 9, 305-313. doi: 10.1099/00221287-9-2-305

Lim, C. H., Lettmann, K., and Wolff, J.-O. (2013). Numerical study on wave dynamics and wave-induced bed erosion characteristics in potter cove, antarctica. Ocean Dyn. 63, 1151-1174. doi: 10.1007/s10236-013-0651-z

Longhi, M. L., Schloss, I. R., and Wiencke, C. (2003). Effect of irradiance and temperature on photosynthesis and growth of two antarctic benthic diatoms. gyrosigma subsalinum and odontella litigiosa. Botanica Marina 46, 276-284. doi: 10.1515/BOT.2003.025

McMinn, A., Ashworth, C., Bhagooli, R., Martin, A., Salleh, S., Ralph, P., et al. (2012). Antarctic coastal microalgal primary production and photosynthesis. Mar. Biol. 159, 2827-2837. doi: 10.1007/s00227-012-2044-0

McMinn, A., Pankowskii, A., Ashworth, C., Bhagooli, R., Ralph, P., and Ryan, K. (2010). In situ net primary productivity and photosynthesis of antarctic sea ice algal, phytoplankton and benthic algal communities. Mar. Biol. 157, 1345-1356. doi: $10.1007 / \mathrm{s} 00227-010-1414-8$

Monien, D., Monien, P., Brünjes, R., Widmer, T., Kappenberg, A., Busso, A. A. S., et al. (2017). Meltwater as a source of potentially bioavailable iron to antarctica waters. Antarct. Sci. 29, 277-291. doi: 10.1017/S0954102016 00064X

Palmisano, A. C., SooHoo, J. B., White, D. C., Smith, G. A., Stanton, G. R., and Burckle, L. H. (1985). Shade adapted benthic diatoms beneath antarctic sea ice. J. Phycol. 21, 664-667. doi: 10.1111/j.0022-3646.1985.00664.x

Paolo, F. S., Fricker, H. A., and Padman, L. (2015). Volume loss from antarctic ice shelves is accelerating. Science 348, 327-331. doi: 10.1126/science.aaa0940

Pasotti, F., Manini, E., Giovannelli, D., Wölfl, A.-C., Monien, D., Verleyen, E., et al. (2015). Antarctic shallow water benthos in an area of recent rapid glacier retreat. Mar. Ecol. 36, 716-733. doi: 10.1111/maec.12179

Peters, G. (2007). Userfriendlyscience: Quantitative Analysis Made Accessible. R Package Version 0.6-1.

Pickett, S. T. A., Kolasa, J., Armesto, J. J., and Collins, S. L. (1989). The ecological concept of disturbance and its expression at various hierarchical levels. Oikos 54, 129-136. doi: $10.2307 / 3565258$

Quartino, M. L., Deregibus, D., Campana, G. L., Latorre, G. E. J., and Momo, F. R. (2013). Evidence of macroalgal colonization on newly ice-free areas following glacial retreat in potter cove (south shetland islands), antarctica. PLoS One 8:e58223. doi: 10.1371/journal.pone.0058223

R Core Team (2017). R: A Language and Environment for Statistical Computing. Vienna: R Foundation for Statistical Computing. Available at: http://www.Rproject.org/

Redfield, A. C. (1934). On the Proportions of Organic Derivatives in Sea Water and Their Relation to the Composition of Plankton. Liverpool: University Press of Liverpool.

Redfield, A. C., Ketchum, B. H., and Richards, F. A. (1963). "The influence of organisms on the composition of seawater," in The Sea, ed. M. N. Hill (New York, NY: Wiley), 26-77.

Rivkin, R. B., and Putt, M. (1987). Photosynthesis and cell division by antarctic microalgae: comparison of benthic, planktonic and ice algae. J. Phycol. 23, 223-229. doi: 10.1111/j.1529-8817.1987.tb04129.x

Round, F. E. (1979). A diatom assemblage living below the surface of intertidal sand flats. Mar. Biol. 54, 219-223. doi: 10.1007/BF00395784
Rückamp, M., Braun, M., Suckro, S., and Blindow, N. (2011). Observed glacial changes on the king george island ice cap, antarctica, in the last decade. Glob. Planet. Change 79, 99-109. doi: 10.1016/j.gloplacha.2011.06.009

Sahade, R., Lagger, C., Torre, L., Momo, F., Monien, P., Schloss, I., et al. (2015). Climate change and glacier retreat drive shifts in an antarctic benthic ecosystem. Sci. Adv. 1, e1500050. doi: 10.1126/sciadv.1500050

Schloss, I. G., Ferreyra, G. A., Mercuri, G., and Kowalke, J. (1999). Particle flux in an Antarctic shallow coastal environment: a sediment trap study. Sci. Mar. 63, 99-111. doi: 10.3989/scimar.1999.63s199

Schloss, I. G., Ferreyra, G. A., and Ruiz-Pino, D. (2002). Phytoplankton biomass in antarctic shelf zones: a conceptual model based on potter cove, king george island. J. Mar. Syst. 36, 129-143. doi: 10.1016/S0924-7963(02)00183-5

Schloss, I. G., Ferreyra, G. A., Curtosi, A., Klöser, H., Mercuri, G., and Pinola, E. (1997). "Factors governing phytoplankton and particulate matter variation in Potter Cove, King George Island Antarctica," in Antarctic Communities, eds B. Battaglia, J. Valencia, and D. W. H. Walton (Cambridge: Cambridge University Press), 135-141.

Schloss, I. R., Abele, D., Moreau, S., Demers, S., Bers, A., González, O., et al. (2012). Response of phytoplankton dynamics to 19-year (1991-2009) climate trends in potter cove (antarctica). J. Mar. Syst. 92, 53-66. doi: 10.1016/j.jmarsys.2011.10. 006

Schloss, I. R., Ferreyra, G. A., and Curtosi, A. (1998). "Phytoplankton primary production in Potter Cove, King George Island," in The Potter Cove Coastal Ecosystem, Antarctica: Synopsis of Research Performed within the Frame of the Argentinean - German Cooperation at the Dallmann Laboratory and Jubany Station (King George Island, Antarctica, 1991-1997), eds C. Wiencke, G. A. Ferreyra, W. Arntz, and C. Rinaldi (Reports of Polar Research), 67-73.

Scott, F. J., and Thomas, D. P. (2005). "Diatoms," in Antarctic Marine Protists, eds F. J. Scott, and H. J. Marchant (Hobart, TAS: Australian biological resources study), 13-201.

Skowronski, R. S., de Gheller, P. F., Bromberg, S., David, C. J., Petti, M. A., and Corbisier, T. N. (2009). Distribution of microphytobenthic biomass in martel inlet, king george island (antarctica). Polar Biol. 32, 839-851. doi: 10.1007/ s00300-009-0584-7

Sun, J., and Liu, D. (2003). Geometric models for calculating cell biovolume and surface area for phytoplankton. J. Plankton Res. 25, 1331-1346. doi: 10.1093/ plankt/fbg096

Sundbäck, K., Nilsson, P., Nilsson, C., and Jönsson, B. (1996). Balance between autotrophic and heterotrophic components and processes in microbenthic communities of sandy sediments: a field study. Estuar. Coast. Shelf Sci. 43, 689-706. doi: 10.1006/ecss.1996.0097

Torre, L., Servetto, N., Eöry, M. L., Momo, F., Tatián, M., Abele, D., et al. (2012). Respiratory responses of three antarctic ascidians and a sea pen to increased sediment concentrations. Pol. Biol. 35, 1743-1748. doi: 10.1007/s00300-0121208-1

Torre, L., Tabares, P. C. C., Momo, F., Meyer, J. F. C. A., and Sahade, R. (2017). Climate change effects on antarctic benthos: a spatially explicit model approach. Clim. Change 141, 733-746. doi: 10.1007/s10584-0171915-2

Witkowski, A., Lange-Bertalot, H., and Metzeltin, D. (2000). Diatom Flora of Marine Coasts I. Iconographia Diatomologica. A.R.G. Ruggell: Gantner Verlag.

Woelfel, J., Schumann, R., Peine, F., Flohr, A., Kruss, A., Tegowski, J., et al. (2010). Microphytobenthos of arctic kongsfjorden (svalbard, norway): biomass and potential primary production along the shore line. Pol. Biol. 33, 1239-1253. doi: $10.1007 / \mathrm{s} 00300-010-0813-0$

Wright, S. W., and Jeffrey, S. W. (1997). "High-resolution HPLC system for chlorophylls and carotenoids of marine phytoplankton," in Phytoplankton Pigments in Oceanography: Guidelines to Modern Methods, eds S. W. Jeffrey, R. F. C. Mantoura, and S. W. Wright (Paris: UNESCO), 327-341.

Wulff, A., Roleda, M. Y., Zacher, K., and Wiencke, C. (2008a). Exposure to sudden light burst after prolonged darkness - a case study on benthic diatoms in antarctica. Diatom Res. 23, 519-532. doi: 10.1080/0269249x.2008. 9705774

Wulff, A., Roleda, M. Y., Zacher, K., and Wiencke, C. (2008b). UV radiation effects on pigments, photosynthetic efficiency and DNA of a semi-natural antarctic marine benthic diatom community. Aquat. Biol. 3, 167-177. doi: 10.3354/ ab00076 
Wulff, A., Sundbäck, K., Nilsson, C., Carlson, L., and Jönsson, B. (1997). Effect of sediment load on the microbenthic community of a shallow-water sandy sediment. Estuaries 20, 547-558. doi: 10.2307/1352613

Wulff, A., Iken, K., Quartino, M. L., Al-Handal, A., Wiencke, C., and Clayton, M. N. (2009). Biodiversity, biogeography and zonation of marine benthic micro- and macroalgae in the Arctic and Antarctic. Bot. Mar. 52, 491-507. doi: 10.1515/ BOT.2009.072

Zacher, K., Hanelt, D., Wiencke, C., and Wulff, A. (2007). Grazing and UV radiation effects on an antarctic intertidal microalgal assemblage: a long-term field study. Pol. Biol. 30, 1203-1212. doi: 10.1007/s00300-007$0278-y$
Conflict of Interest: The authors declare that the research was conducted in the absence of any commercial or financial relationships that could be construed as a potential conflict of interest.

Copyright (c) 2019 Hoffmann, Al-Handal, Wulff, Deregibus, Zacher, Quartino, Wenzhöfer and Braeckman. This is an open-access article distributed under the terms of the Creative Commons Attribution License (CC BY). The use, distribution or reproduction in other forums is permitted, provided the original author(s) and the copyright owner(s) are credited and that the original publication in this journal is cited, in accordance with accepted academic practice. No use, distribution or reproduction is permitted which does not comply with these terms. 